\title{
Penyebaran Populasi Nyamuk Aedes aegypti sebagai Vektor Penyakit Demam Berdarah Dengue di Kota Tidore Kepulauan (Distribution of Aedes aegypti Mosquito Population as A Vector of Dengue Fever Disease in Tidore Kepulauan City)
}

\author{
Fahrisal $^{\left.1^{*}\right)}$, Betsy Pinaria ${ }^{1)}$, Dantje Tarore \\ 1) Program Studi Entomologi, Pasca Sarjana Universitas Sam Ratulangi, Manado 95115 \\ ${ }^{\star}$ Email korespondensi: atreyafahrisal@gmail.com
}

Diterima 10 Februari 2019, diterima untuk dipublikasikan 28 Februari 2019

\begin{abstract}
Abstrak
Demam berdarah dengue (DBD) merupakan salah satu masalah kesehatan penting di indonesia saat ini baik di daerah tropis dan suptropis. Penelitian ini bertujuan untuk mengkaji penyebaran populasi nyamuk Ae. aegypti sebagai vektor penularan penyakit DBD di wilayah kerja Puskesmas Soasio Kota Tidore Kepulauan. Penelitian ini dilakukan dengan menggunakan metode survei cara pengambilan sampel yakni dengan pengambilan purposive sampling. Penangkapan nyamuk dilakukan pada setiap kelurahan yaitu 13 kelurahan yang tersebar di wilayah kerja Puskesmas Soasio yaitu tempat-tempat seperti pelayanan kesehatan, pelayanan pendidikan, daerah pemukiman penduduk, dan lahan-lahan kosong di sekitar daerah pemukiman. Hasil penelitian populasi nyamuk Ae. aegypti yang di temukan di Wilayah kerja Puskesmas Soasio mencangkup 13 Kelurahan bervariasi antara 6-23 individu. Populasi Ae. aegypti tertingi di Kelurahan Tuguwaji yaitu 23 individu dan terendah di Kelurahan Tambula yaitu 6 individu. Populasi nyamuk Ae. aegypti terbanyak pada waktu pagi yaitu jam 08:00-10:00 sebanyak 52 individu dan sore hari jam 14:00-16:00 sebanyak 50 individu. Jumlah penderita DBD antara bulan November 2018 sampai bulan Januari 2019 sebanyak 5 orang, yang terdiri dari 3 orang di kelurahan Tuguwaji, satu orang di kelurahan Indonesiana dan 1 orang di kelurahan Tomagoba.

Kata Kunci: Ae. aegypti, Demam berdarah dengue (DBD), penyebaran, populasi
\end{abstract}

\begin{abstract}
Dengue haemorrhagic fever (DHF) is one of the important health problems in Indonesia today both in the tropics and suptropis. Purpose of the study assess population and the spread of mosquitoes. Ae aegypti as a vector of transmission of DHF in the working area of Soasio City Health Center, Tidore Islands. This research was conducted using the survey method of sampling method by taking purposive sampling. The catch of mosquitoes was carried out in each kelurahan, namely 13 urban villages scattered in the work area of the Soasio Health Center, namely places such as health services, education services, residential areas, and vacant land around residential areas. Results of research on mosquito population Ae. aegypti found in the Puskesmas work area of the ratio includes 13 sub-districts varying between 6-23 individuals. population the highest Ae. aegypti in Tuguwaji Village is 23 individuals and the lowest in Tambula Village is 6 individuals. Population of mosquitoes most Ae. aegypti in the morning, which is at 08:00 a.m. to 10:00 a.m. by 52 individuals and in the afternoon at 14:00 to 16:00 as many as 50 individuals. The number of dengue sufferers between November 2018 and January 2019 is 5 people, consisting of 3 people in Tuguwaji village, 1 person in the Indonesiana village and 1 person in Tomagoba village.

Keywords: Ae. aegypti, Dengue Hemorrhagic Fever (DHF), spread, population
\end{abstract}




\section{PENDAHULUAN}

Penyakit Deman Berdarah
Dengue (DBD) di Indonesia
ditemukan pertama kali di Surabaya pada tahun 1968 sebanyak 58 orang terinfeksi dan 24 orang diantaranya meninggal dunia. Angka kematian/ Cese Fatality Rate yang disebabkan oleh penyakit sebesar $41,3 \%$ dan sejak itu, penyakit DBD ini menyebar keseluruh Indonesia. Indonesia mempunyai resiko untuk terjangkit penyakit $\mathrm{DBD}$, kecuali daerah yang memiliki ketingian 1000 meter diatas permukaan laut. Pemerintah telah melakukan berbagai upaya untuk mengendalikan perkembangan vektor Ae. aegypti ini, antara lain dengan cara kimiawi berupa fogging dan insektisida sebagai larvasida pada tempat penampungan air yang sulit dibersihkan. Larvasida dikenal dengan istilah lain yaitu abatisasi. Larvasida yang biasa digunakan adalah Temefos. Insektisida dari bahan kimiawi ternyata menimbulkan banyak masalah baru diantaranya adalah pencemaran lingkungan seperti pencemaran air dan resistensi serangga terhadap insektiasida sehingga perlu adanya insektisida yang lebih aman bagi lingkungan (Depkes RI 2005).

Demam Berdarah Dengue disebabkan oleh virus dengue masih menjadi masalah besar bagi masyarakat dunia terutama di Negara subtropis dan tropis (Indonesia yang memiliki iklim tropis). Di Indonesia nyamuk penular (vektor) penyakit DBD yang penting adalah Aedes aegyptyi, Aedes albopictus, dan Aedes scutellaris, tetapi sampai saat ini yang menjadi vector utama dari penyakit DBD adalah Ae. aegypti (Soegijanto 2004).

Wilayah Kota Tidore Kepulauan terdiri dari dataran, pegunungan dan beriklim tropis. Berdasarkan data dinas Kesehatan pada tahun 20132017 penderita DBD di 10 Puskesmas Kota Tidore Kepulauan dan jumlah keseluruhan yang terjangkit penyakit DBD mencapai 87 orang, tahun 2013 sebanyak 26 orang, 2014 ada 2 orang, 2015 ada 9 orang, 2016 ada 39 orang, 2017 ada 11 orang. Kasus DBD di wilayah kerja Puskesmas Soasio yang paling tinggi dibandingkan dengan wilayah kerja puskesmas lain di Kota Tidore Kepulauan. Puskesmas Soasio memiliki jumlah penderita tertinggi yaitu sebanyak 48 orang yang tersebar di wilayah kerjanya, Puskesmas Soasio meliputi 13 Kelurahan dan setiap Kelurahan menempati wilayah dataran rendah dan dataran tinggi.

Tempat potensial untuk perindukan nyamuk Ae. aegypti adalah tempat Penampungan Air (TPA) yang digunakan sehari-hari yaitu drum, bak mandi, bak wc, gentong, ember dan lain-lain. Tempat perindukan lainnya adalah vas bunga, ban bekas, botol bekas, tempat minum burung, tempat sampah dan lain-lain, serta TPA alamiah, yaitu lubang pohon, daun pisang, pelepah daun keladi, lubang batu, dan lain-lain. Adanya kontainer di tempat ibadah, pasar dan saluran air hujan yang tidak lancar di sekitar rumah juga merupakan tempat perkembangbiakan yang baik (Soegijanto, 2004). Penelitian ini bertujuan untuk mengkaji populasi dan penyebaran nyamuk Ae. aegypti sebagai vektor penularan penyakit DBD di wilayah kerja Puskesmas Soasio Kota Tidore Kepulauan.

\section{METODE PENELITIAN}

Penelitian dilaksanakan di Wilayah kerja Puskesmas Soasio Kota Tidore Kepulauan dengan waktu penelitian selama 3 bulan mualai dari Bulan November 2018 sampai Januari 2019. Penelitian ini mengunakan metode survei dengan cara pengambilan sampel yakni dengan pengambilan purposive sampling (sengaja). 
Pengamatan dilakukan di semua kelurahan di bawah nauangan Puskesmas Soasio. Sebelum melakukan penangkapan dilakukan survei pada beberapa lokasi untuk menentukan lokasi penangkapan. Penangkapan nyamuk pada setiap lokasi dilaksanakan oleh 2 orang di dalam rumah dan 2 orang di luar rumah dan waktu pelaksanaan penangkapan dari jam 06.00 pagi sampai 12.00 siang dilanjutkan dengan 12.00 siang sampai jam 18.00 sore. Penangkapan nyamuk dilakukan di tempat-tempat seperti pelayanan kesehatan, pelayanan pendidikan, daerah pemukiman penduduk dan lahan-lahan kosong di sekitar daerah pemukiman.

Penangkapan Ae. aegypti dilakukan dengan cara penyapuan serangga dan dengan cara penyemprotan secara langsung. Ae. aegypti yang tertangkap diambil dalam jaring atau yang jatuh karena di semprot, kemudian dimasukkan ke dalam botol plastik kecil, dan di beri label lokasi, tanggal dan jam. Nyamuk dewasa yang tertangkap diidentifikasi langsung dengan menggunakan mikroskop. Cara penangkapan tidak mengunakan umpan manusia karena menggandung resiko yang berbahaya karena sewaktu nyamuk menghisap darah dapat terjadi transmisi virus dengue.

\section{HASIL DAN PEMBAHASAN}

Hasil identifikasi jenis pada bagian dorsal thorak terdapat sepasang garis lengkung di bagian luar dangan garis pendek di bagian tengah yang membentuk lira yaitu lyre marketing yang merupakan satu gambaran putih keperakan di bagian luar. Pada bagian tengahnya terdapat dua garis pendek membentuk lira yaitu lire marketing yang merupakan satu gambaran putih keperakan di daerah dorsal thoraks (Gambar 1).

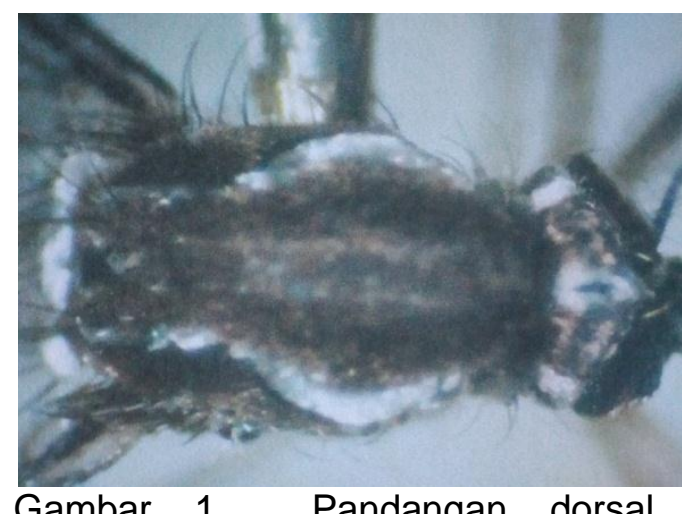

thoraks Ae. aegypti.

Populasi nyamuk Ae. aegypti yang ditemukan di wilayah kerja Puskesmas Soasio yang mencakup 13 Kelurahan bervariasi antara 6-23 individu. Populasi Ae. aegypti tertingi di Kelurahan Tuguwaji yaitu 23 individu dan terendah pada Kelurahan Tambula yaitu 6 individu. Populasi nyamuk Ae. aegypti pada 13 kelurahan yang tebanyak pada pagi hari yaitu jam 08:00-10:00 Wit dengan jumlah nyamuk 52 individu dan sore hari jam 14:00-16:00 wit dengan jumlah 50 individu (Tabel 1 dan 2).

Hasil penelitian menunjukan bahwa populasi nyamuk Ae. aegypti telah menyebar di semua kelurahan yaitu 13 kelurahan di bawah naungan Puskesmas Soasio. Hal ini menunjukan bahwa nyamuk $A e$. aegypti beraktifitas pada jam 06:00 pagi sampai jam 18:00 sore dan terbayak aktifitas ada pada pagi hari yaitu 08.00-10.00 Wit dan sore hari jam 14.00-16.00 Wit. Hal ini disebabkan beberapa warga yang belum memiliki kesedaran akan pentingnya kebersihan di dalam rumah. 
Tabel 1. Populasi Nyamuk Ae.aegypti pada 13 kelurahan

\begin{tabular}{|c|c|c|c|c|c|c|c|c|}
\hline \multirow[b]{2}{*}{ Kelurahan } & \multicolumn{6}{|c|}{ Rata-Rata Populasi } & \multirow[b]{2}{*}{ Jumlah } & \multirow[b]{2}{*}{ Rataan } \\
\hline & $\begin{array}{l}06.00- \\
08.00\end{array}$ & $\begin{array}{c}08.00- \\
10.00\end{array}$ & $\begin{array}{l}10.00- \\
12.00\end{array}$ & $\begin{array}{c}12.00- \\
14.00\end{array}$ & $\begin{array}{l}14.00- \\
16.00\end{array}$ & $\begin{array}{l}16.00- \\
18.00\end{array}$ & & \\
\hline Selly & 2 & 3 & 3 & 0 & 2 & 1 & 11 & 1,9 \\
\hline Soadara & 1 & 3 & 1 & 1 & 3 & 1 & 10 & 1,7 \\
\hline Soasio & 2 & 5 & 1 & 1 & 4 & 2 & 15 & 2,5 \\
\hline Gam 8 & 0 & 7 & 4 & 2 & 3 & 2 & 18 & 3,0 \\
\hline Tomagoba & 1 & 8 & 2 & 0 & 2 & 2 & 15 & 2,5 \\
\hline Tupo 3 & 0 & 7 & 1 & 0 & 3 & 1 & 12 & 2,0 \\
\hline Topo & 1 & 4 & 2 & 3 & 2 & 0 & 12 & 2,0 \\
\hline Tambula & 0 & 2 & 1 & 0 & 3 & 1 & 6 & 1,0 \\
\hline Folarora & 2 & 2 & 1 & 2 & 3 & 2 & 12 & 2,0 \\
\hline Gurabunga & 3 & 1 & 1 & 2 & 6 & 2 & 15 & 2,5 \\
\hline Tuguwaji & 1 & 6 & 2 & 1 & 10 & 3 & 23 & 3,9 \\
\hline Indonesiana & 1 & 2 & 2 & 0 & 4 & 2 & 11 & 1,9 \\
\hline Goto & 4 & 2 & 3 & 3 & 5 & 1 & 18 & 3,0 \\
\hline Jumlah & 18 & 52 & 24 & 15 & 50 & 20 & 178 & 29.9 \\
\hline Rata-rata & 1.4 & 4.0 & 1.9 & 1.2 & 3.9 & 1.5 & & 9.96 \\
\hline
\end{tabular}

Beberapa kebiasaan masyarakat yang menyebabkan banyaknya nyamuk seperti banyak pakaian yang tergantung dan berserakan di mana-mana, hal ini menyebabkan nyamuk Ae. aegypti banyak bersarang. Tempat penampungan air (TPA) berupa drum yang sangat banyak dan tidak terawat serta setiap drum banyak jentik nyamuk yang terlihat, tapi TPA penampungan lain seperti bak penampung sangat bersih. Banyak warga yang melakukan aktivitas pada pagi hari, siang hari di luar rumah dan pada sore hari khususnya penghuni rumah telah berkumpul kembali setelah melakukan aktivitas.
Warga yang sudah masuk dalam rumah setelah beraktivitas adalah sumber makanan (darah) untuk nyamuk dan tidak menutup kemungkinan Ae. aegypti beraktifitas pada malam hari. Hasil penelitian Syahribulan et al. (2012) yang mengunakan umpan manusia melaporkan bahwa nyamuk yang tertangkap ada 10 dan aktif menghisap dara pada malam hari. Dieng et al. (2010) dalam hasil penelitianya di Sumenanjang Utara Malaysia juga melaporkan bahwa nyamuk Ae. aegypti ditemukan menghisap darah pada malam hari pukul 20:00-03:00 Wit dini hari.

Tabel 2. Populasi nyamuk pagi dan sore hari

\begin{tabular}{ccc}
\hline Waktu (WIT) & Jumlah (Individu) & Rataan \\
\hline $06.00-08.00$ & 18 & 1,4 \\
$08.00-10.00$ & 52 & 4,0 \\
$10.00-12.00$ & 24 & 1,9 \\
$12.00-14.00$ & 15 & 1,2 \\
$14.00-16.00$ & 50 & 3,9 \\
$16.00-18.00$ & 20 & 1,5 \\
\hline
\end{tabular}

Berdasarkan data kasus demam berdarah menurut Dinas Kesehatan Kota Tidore Kepulauan yang banyak terjangkit penyakit DBD dari 3 bulan penelitian adalah Kelurahan Tuguwaji. Hal ini ada 
hubungannya dengan populasi nyamuk Ae. aegypti (Tabel 2), karena terdapat vasilitas Kesehatan berupa Rumah Sakit Daerah (RSD) yang satu-satunya di Tidore, daerah pemukiman penduduk dan terletak di pesisir pantai dan ada tempat sampah milik RSD yang juga dipakai warga sekitar untuk tempat pembuangan sampah. Nyamuk Ae. aegypti tidak semuanya pembawa virus DBD, hanya apabila nyamuk Ae. aegypti betina yang pernah menggigit manusia yang terkena penyakit DBD yang berpotensi dapat memindahkan virusnya ke manusia yang sehat di sekitarnya. Menurut Sorisi (2013) bahwa tidak semua nyamuk mengandung virDen karena tidak semua Ae. aegypti bisa menjadi vektor DBD. Transmisi virDen umumnya terjadi secara horisontal dari manusia pembawa virDen ke nyamuk vektor Aedes sp. yang setelah mengalami propagasi dalam tubuh nyamuk akan di tularkan ke manusia penerima.

Tabel 3. Penderita DBD dari Bulan November 2018 sampai Januari 2019

\begin{tabular}{lccc}
\hline \multirow{2}{*}{ Kelurahan } & \multicolumn{3}{c}{ Tahun } \\
\cline { 2 - 4 } & November & Desember & Januari \\
& 2018 & 2018 & 2019 \\
\hline Tuguwaji & 3 & 0 & 0 \\
Indonesiana & 0 & 1 & 0 \\
Tomagoba & 0 & 0 & 1 \\
\hline Jumlah & 3 & 1 & 1 \\
\hline
\end{tabular}

Sumber: Dinas kesehatan Kota Tidore Kepulauan

Selama 3 bulan penelitian pada bulan November 2018 sampai Januari 2019 menunjukan bahwa penderita DBD dari 13 kelurahan hanya ada 3 kelurahan yang terjangkit penyakit DBD. Jumlah penederita DBD pada bulan November 2018 ada 3 orang di Kelurahan Tuguwaji dan Desember ada satu orang dari Kelurahan Indonesiana. Pada tahun 2019 bulan Januari ada satu penderita DBD dari Kelurahan Tomagoba (Tabel 3). Jadi selama 3 bulan penelitian didapatkan 5 orang yang terjangkit penyakit Demam Berdarah (DBD) yang disebabkan oleh nyamuk $A e$. aegypti

\section{KESIMPULAN}

Hasil penelitian menunjukan bahwa nyamuk $A e$. aegypti tersebar di 13 kelurahan dinyatakan dengan populasi nyamuk yang tertangkap dan dikoleksi didapat disemua kelurahan wilayah kerja Puskesmas
Soasio. Populasi nyamuk tertinggi di wilayah kerja Puskesmas Soasio Kota Tidore Kepulauan ditemukan pada Kelurahan Tuguwaji dan terendah pada Kelurahan Tambula. Populasi nyamuk Ae. aegypti di temukan pada jam 06.00 pagi sampai jam 18.00 sore. Populasi nyamuk terbanyak pada pagi hari yaitu 08.00-10.00 Wit dengan jumlah 52 individu dan sore hari jam 14.0016.00 Wit dengan jumlah 50 individu. Hasil penelitian selama 3 bulan dari Bulan November 2018 sampai Bulan Januari 2019 ditemukan 5 kasus DBD di wilayah Kerja Puskesmas Soasio.

\section{DAFTAR PUSTAKA}

Dieng $H$, Saiful RGM, Hassan AA, Salma, MRC, Boots M (2010) Indoor-Breeding of Aedes albopictus in northem 
peninsular Malaisya and its potential epidemological implication. Plos ONE, 5(7):117-90.

Dinkes Kota Tidore Kepulauan (2018) Laporan tahunan demam berdarah dengue Kota Tidore Kepulauan. Dinas Kesehatan Kota Tidore Kepulauan.

Dinkes Kota Tidore Kepulauan (2019) Laporan tahunan demam berdarah dengue Kota Tidore Kepulauan. Dinas Kesehatan Kota Tidore Kepulauan.

Depkes RI. (2005) Demam berdarah Dengue.

http://www.depkes.go.id. $\quad 10$ Maret 2018

Rueda ML (2004) Zootaxa. Pictorial keys for the indentifikation of mosqueto (Diptera: culicidae). associated with Dengue Virus Transmission. Magnolia Press. 589: 1-60.
Sorisi AMH (2013) Taransmisi transovarial virus dengue pada nyamuk Aedes spp. Jurnal Biomedik, Vol 5 (1): 26-31

Soegijanto, S (2004). Demam Berdarah Dengue. Surabaya: Airlangga University Press.

Syahribulan, Fince MB, Munif SH (2012) Period of sucking activity of Aedes aegypti and Aedes albopictus Mosqueto at $\mathrm{Pa} \quad$ lanassang Village Barombong District Makassar south Sulawesi. Universitas Hsanudin. Jurnal ekologi Kesehatan, Vol 11 (4): 306314.

Wuwungan A, Antje (2012) Penentuan Serotipe virus dengue pada nyamuk Aedes aegypti sebagai vektor dengan penderita demam dengue di Manado Provinsi Sulawesi Utara. Disertasi. Universitas Sam Ratulagi. Manado. 